\title{
Pseudomonas atagosis sp. nov., and Pseudomonas akappagea sp. nov., New Soil Bacteria Isolated from Samples on the Volcanic Island Izu Oshima, Tokyo
}

\author{
Yuh Morimoto $^{1} \cdot$ Kazuki Uwabe $^{2} \cdot$ Mari Tohya $^{3} \cdot$ Keiichi Hiramatsu $^{1} \cdot$ Teruo Kirikae $^{3} \cdot$ Tadashi Baba $^{1}$
}

Received: 9 October 2019 / Accepted: 3 March 2020 / Published online: 18 March 2020

(c) The Author(s) 2020

\begin{abstract}
During the exploration of microbial natural resources, two strains of Pseudomonas, PS14 ${ }^{\mathrm{T}}$ and PS2 $4^{\mathrm{T}}$, were isolated from samples taken from Izu Oshima, a volcanic island located $120 \mathrm{~km}$ southwest of central Tokyo. Phylogenetic analysis based on 16S rRNA gene sequences showed that $\mathrm{PS}_{14}{ }^{\mathrm{T}}$ was most similar to Pseudomonas baetica a390 ${ }^{\mathrm{T}}(99.6 \%)$ and Pseudomonas helmanticensis $\mathrm{OHA} 11^{\mathrm{T}}(99.5 \%)$, and that $\mathrm{PS} 24^{\mathrm{T}}$ was most similar to Pseudomonas qingdaonensis $\mathrm{JJ} 3^{\mathrm{T}}(98.8 \%)$ and Pseudomonas lutea $\mathrm{OK}^{\mathrm{T}}(98.7 \%)$. The major fatty acids of these two strains were $\mathrm{C}_{16: 0}$ and $\mathrm{C}_{17: 0}$ cyclo, summed feature $3\left(\mathrm{C}_{16: 1}\right.$ $\omega 6 \mathrm{c}$ and/or $\left.\mathrm{C}_{16: 1} \omega 7 \mathrm{c}\right)$, and summed feature $8\left(\mathrm{C}_{18: 1} \omega 7 \mathrm{c}\right.$ and/or $\left.{ }_{18: 1} \omega 6 \mathrm{c}\right)$. The phylogenetic analyses, DNA-DNA hybridization results and phenotypic traits indicated that PS14 ${ }^{\mathrm{T}}$ and $\mathrm{PS} 24^{\mathrm{T}}$ constitute two novel species, Pseudomonas atagosis sp. nov. (type strain PS14 ${ }^{\mathrm{T}}=$ CECT $9940^{\mathrm{T}}$, $=$ LMG $31496^{\mathrm{T}}$ ) and Pseudomonas akappagea sp. nov. $\left(\right.$ type strain PS24 ${ }^{\mathrm{T}}=\mathrm{CECT}$ $9941^{\mathrm{T}}$, = LMG $31497^{\mathrm{T}}$ ), respectively. The sequence data of the draft genomes of PS14 ${ }^{\mathrm{T}}$ and PS24 ${ }^{\mathrm{T}}$ were deposited in the GenBank database under accession numbers VXCA00000000 and VXCP00000000, respectively, and the sequence data of their 16S rRNA genes were deposited in the GenBank database under accession numbers MN396717 and MN382268, respectively.
\end{abstract}

\section{Introduction}

The genus Pseudomonas was first described at the end of the nineteenth century [1]. Pseudomonas strains are Gramnegative, rod-shaped, motile, catalase-positive and oxidasepositive bacterial cells. These bacteria have been isolated from various environments worldwide, including soil, animals, plants, and water [2]. To date, the List of Prokaryotic Names with Standing in Nomenclature (https://www.bacte

Electronic supplementary material The online version of this article (https://doi.org/10.1007/s00284-020-01943-2) contains supplementary material, which is available to authorized users.

Tadashi Baba

tbaba@juntendo.ac.jp

1 Center of Excellence for Infection Control Science, Graduate School of Medicine, Juntendo University, 2-1-1 Hongo, Bunkyo-ku, Tokyo 113-8421, Japan

2 School of Medicine, Juntendo University, 2-1-1 Hongo, Bunkyo-ku, Tokyo 113-8421, Japan

3 Department of Microbiology, Faculty of Medicine, Juntendo University, 2-1-1 Hongo, Bunkyo-ku, Tokyo 113-8421, Japan rio.net) includes 255 species of Pseudomonas, including 18 subspecies.

During the exploration of microbial natural resources, we collected soil samples from Izu Oshima, in January 2017. PS14 ${ }^{\mathrm{T}}$ was isolated from soil collected at Mt. Atago, which is located in the northwest part of the island. Mt. Atago, where Castanopsis sieboldii trees grow, is the transitional final stage, known as a climax community. PS $24^{\mathrm{T}}$ was isolated from a red scoria cone located on the west coast of the island, which the local inhabitants call Akappage. The present study describes the phenotypic and phylogenic characteristics of these two strains. These characteristics indicate that these two strains represent novel species of the genus Pseudomonas.

\section{Materials and Methods}

\section{Strains and Growth Conditions}

Approximately $5 \mathrm{~g}$ of the ground surface was collected at eight locations on Izu Oshima, including Mt. Atago (34 $\left.77^{\prime} 06^{\prime \prime} \mathrm{N}, 139^{\circ} 35^{\prime} 98^{\prime \prime} \mathrm{E}\right)$ and Akappage (34 $77^{\prime} 50^{\prime \prime} \mathrm{N}$, $\left.139^{\circ} 34^{\prime} 99^{\prime \prime} \mathrm{E}\right)$. Approximately $0.5 \mathrm{~g}$ of soil samples were 
suspended in $5 \mathrm{ml}$ of $0.9 \% \mathrm{NaCl}$ solution, and $0.1 \mathrm{ml}$ of the suspension of each sample was spread onto Pseudomonas spp. selective medium (Pseudomonas CFC/CN agar, Merck). The plates were incubated for $48 \mathrm{~h}$ at room temperature. 20 and 76 colonies appeared from the Mt. Atago and Akapage samples, and several colonies with different colony morphologies were selected and purified with a single colony isolation. PS14 ${ }^{\mathrm{T}}$ and PS2 $24^{\mathrm{T}}$ were two of the selected isolates. The reference strains Pseudomonas helmanticensis LMG $28168^{\mathrm{T}}$, Pseudomonas lutea LMG $21974^{\mathrm{T}}$, Pseudomonas rhizosphaerae LMG $21640^{\mathrm{T}}$ and Pseudomonas bohemica LMG $30182^{\mathrm{T}}$ were obtained from Belgian Coordinated Collections Microbiology (BCCM). Pseudomonas koreensis JCM $14769^{\mathrm{T}}$ and Pseudomonas qingdaonensis $\mathrm{JCM} 32579^{\mathrm{T}}$ were provided by the RIKEN BRC through the National BioResource Project of the MEXT/AMED, Japan. Pseudomonas helmanticensis LMG $28168^{\mathrm{T}}$ and Pseudomonas bohemica LMG $30182^{\mathrm{T}}$ were imported under the permit of the Minister of Agriculture, Forestry and Fisheries, Japan, in accordance with the Plant Protection Law. All these strains were cultured in tryptic soy broth (TSB, Becton Dickinson).

\section{Morphological, Physiological and Biochemical Studies}

Cell morphology was examined by scanning electron microscopy (Hitachi S-4800). Colony morphology was assessed on tryptic soy agar (TSA, Becton Dickinson) plates after culture for $24 \mathrm{~h}$ at $28^{\circ} \mathrm{C}$. Growth at various temperatures was tested by culturing in Luria-Bertani broth (LB, Becton Dickinson) [3]. Briefly, overnight cultures of tested strains were adjusted to $\mathrm{OD}_{600 \mathrm{~nm}}=0.225$, and $20 \mu \mathrm{l}$ of each sample were inoculated into $10 \mathrm{ml}$ of LB. These strains were incubated at 5, $8,12,24,28,32,36$ and $40^{\circ} \mathrm{C}$ while shaking at $25 \mathrm{rpm}$ in a photorecording incubator (TN-2612; ADVANTEC, Tokyo, Japan). Gram-staining was performed by a staining kit (Muto Pure Chemicals co. Itd, Tokyo Japan). Motility was directly assessed using a Bacteria Self-Checker mil-kin ${ }^{\circledR}$ (https:// www.mil-kin.com/). Fluorescent pigmentation was assessed on King B medium (Eiken, Tokyo Japan), as described previously [4]. Oxidase activity as assessed using Cytochrome Oxidase Test Strips (Nissui, Tokyo, Japan). Catalase activity was analyzed by dropping 3\% hydrogen peroxide solution onto the cells and monitoring the production of bubbles. Growth at different $\mathrm{NaCl}$ concentrations was assessed in nutrient broth (Becton Dickinson) [3] containing 0, 1, 2, 3, 4, 5, 6 and 7\% $\mathrm{NaCl}$. Growth at different $\mathrm{pH}$ levels $(5,6,7$, 8,9 , and 10) was investigated by adding hydrochloric acid or sodium hydroxide to $7.5 \mathrm{ml}$ of twofold-higher TSB and $3 \mathrm{ml}$ of buffer agent (MOPS for $\mathrm{pH} 5$ to $\mathrm{pH} 7$, HEPES for $\mathrm{pH} 8$ to $\mathrm{pH} 9$, and CAPS for $\mathrm{pH} 9$ to $\mathrm{pH} 10$ ). The broth was diluted with sterile water to adjust the TSB concentration to onefold. API 20 NE strips (bioMérieux) and Biolog GN3 MicroPlates were used according to the manufacturers' instructions. API $20 \mathrm{NE}$ and GN3 tests for Pseudomonas granadensis DSM $28040^{\mathrm{T}}$ was performed by German Collection of Microorganisms and Cell Cultures GmbH (DSMZ).

\section{Chemotaxonomic Characterization}

Fatty acid methyl ester analysis was performed at Techno Suruga Laboratory Co., Ltd (Shizuoka, Japan). Fatty acids were prepared as described by MIDI Microbial Identification System [5] and analyzed using the Sherlock Microbial Identification (MIDI) system (version 6.0).

\section{Genomic DNA Preparation, Sequencing, and Assembly}

Genomic DNA was extracted from PS $14^{\mathrm{T}}$ and PS $24^{\mathrm{T}}$ using QIAamp DNA Mini Kits (Qiagen), and genomic libraries of both strains were prepared using Nextera XT DNA Library Preparation Kits (Illumina). Paired-end sequencing was performed using MiSeq Reagent Kits v3 (600-cycles) through the Illumina MiSeq platform. De novo assembly was performed using CLC Genomics Workbench v7 (Qiagen). The DNA sequences of the 16S rRNA genes were analyzed using BigDye ${ }^{\circledR}$ Terminator v3.1 Cycle Sequencing Kits and an ABI PRISM 3100 Genetic Analyzer (Applied Biosystems, Life Technologies, Carlsbad, CA), along with the primers 8F (5'-AGA GTTTGATCCTGGCTCAG-3') and 1541R (5'-AAGGAG GTGATCCAGCCGCA-3') [6].

\section{Phylogenetic Analysis}

Sequences were aligned using CLUSTAL W software and phylogenetic trees were constructed using MEGA 7.0 software [7]. Evolutionary distances were calculated using Tamura's 3-parameter model [8]. To account for heterogeneity of substitution rate among nucleotide sites, the discrete gamma model with 5 categories was used. Phylogenetic trees were reconstructed using maximum-likelihood (ML) methods [9]. The sequences of all Pseudomonas type strains used for the analysis except Pseudomonas helmanticensis LMG $28168^{\mathrm{T}}$ were retrieved from the National Center for Biotechnology Information (NCBI) GenBank database and EzBioCloud (https://www.ezbiocloud.net/). Pseudomonas helmanticensis LMG $28168^{\mathrm{T}}$ (GOLD ID Gp0112928) was retrieved from Department of Energy Joint Genome Institute (https://www.jgi.doe.gov) under Genomes Online Database IMG. 


\section{Genome Analysis}

The similarity of the sequenced genomes to genomes of other type strains was determined based on the Average Nucleotide Identity with OrthoANIu algorithm [10] and Genome-to-Genome-Distance (GGDC) version 2.1 software [11]. The GGDC results were based on formula 2, which is independent of genome length and is therefore recommended to use for incomplete draft genomes.

\section{Results and Discussion}

Phylogenetic trees were constructed based on the $16 \mathrm{~S}$ rRNA sequences (1459 bp) of PS14 ${ }^{\mathrm{T}}$ and PS24 ${ }^{\mathrm{T}}$ and of representative Pseudomonas strains (Fig. 1). GenBank accession numbers are listed in Table $\mathrm{S} 1$. The highest interspecific sequence similarities that were found between strain PS $14^{\mathrm{T}}$ and its phylogenetic neighbors were Pseudomonas baetica $\mathrm{a} 390^{\mathrm{T}}(99.6 \%)$ and $P$. helmanticensis OHA $11^{\mathrm{T}}(99.5 \%)$, and that of PS $24^{\mathrm{T}}$ were $P$. qingdaonensis $\mathrm{JJ}^{\mathrm{T}}(98.8 \%)$ and P. lutea $\mathrm{OK} 2^{\mathrm{T}}(98.7 \%)$.

Figure 2 is a phylogenetic tree constructed based on concatenated sequences of 16S rRNA and three housekeeping genes linked in the order 16S rRNA (1459 bp)-gyrB (801 bp)-rpoD (718 bp) -rpoB (915 bp) (Fig. 2). These sequences were retrieved from the genome sequences, and GenBank accession numbers of these genes are listed in Tables S1 and S2. Strain PS14 ${ }^{\mathrm{T}}$ clusters in a separate branch that is related to a group including P. baetica, $P$. helmanticensis and P. koreensis. PS2 $4^{\mathrm{T}}$ was placed near $P$. qingdaonensis and $P$. rhizosphaerae. These results indicate that both of these Izu Oshima strains belong to the $P$. fluorescens lineage, but they are distinct from other species in that lineage.

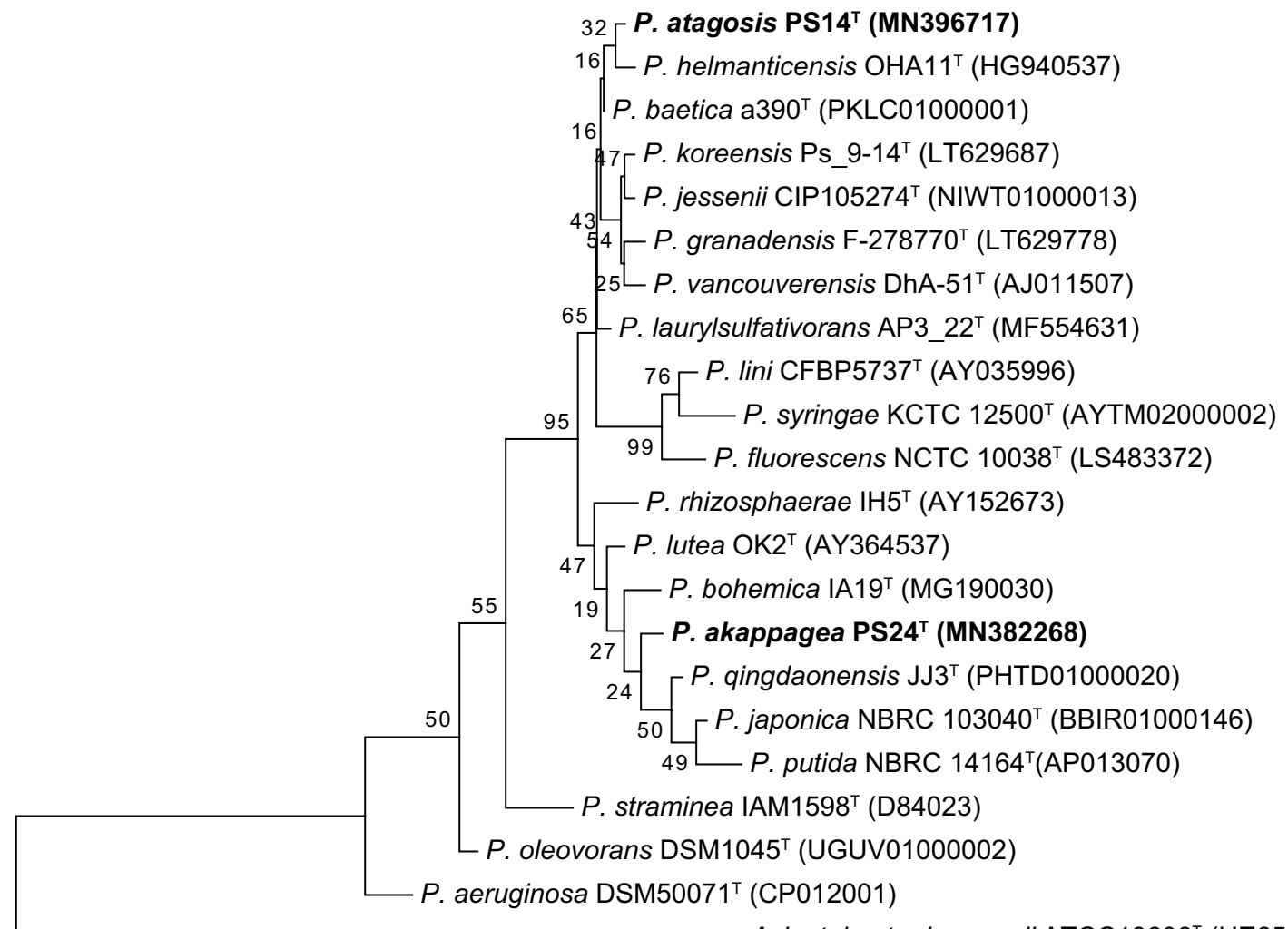

Acinetobacter baumanii ATCC19606 ${ }^{\top}$ (HE651907)

0.050

Fig. 1 Maximum-likelihood (ML) tree based on 16S rRNA gene sequences (1459 bp) showing the relationships of the strains, $P$. atagosis sp. nov. PS14 ${ }^{\mathrm{T}}$ and $P$. akappagea sp. nov. PS24 ${ }^{\mathrm{T}}$, with related type strains of the genus Pseudomonas. The ML tree was reconstructed using Tamura's 3-parameter model+G. The dis- crete gamma model with 5 categories were used. Bootstrap values, expressed as percentages of 1000 replications, are shown at the branching points. GenBank accession numbers are given in parentheses and in Table S1 
Fig. 2 Maximum-likelihood (ML) tree based on the sequences of the housekeeping genes, $16 \mathrm{~S}$ rRNA, gyrB, $r p o D$ and $r p o B$, showing the relationships of the strains, $P$. atagosis sp. nov. PS14 ${ }^{\mathrm{T}}$ and P. akappagea sp. nov. PS24 $4^{\mathrm{T}}$, with related Pseudomonas type strains. The ML tree was reconstructed using Tamura's 3-parameter model $+\mathrm{G}$. The discrete gamma model with 5 categories were used. Bootstrap values, expressed as percentages of 1000 replications, are shown at the branching points. Grey boxes indicate that the strains of this study and the closest type strain based on 16S rRNA comparison. The accession numbers of each sequence are listed in

Tables S1 and S2

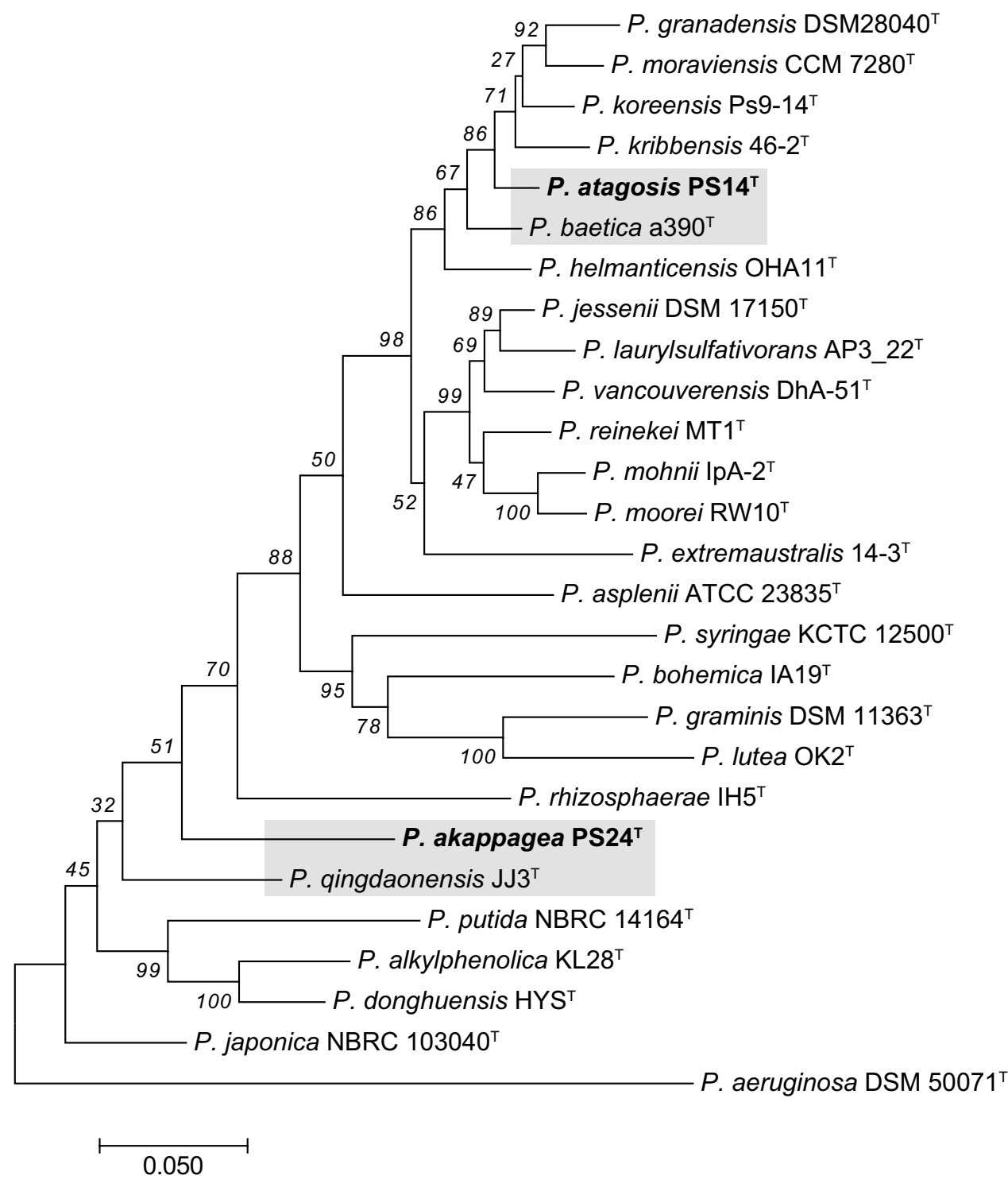

\section{Genomic Analysis}

The DNA G+C contents of PS $14^{\mathrm{T}}$ and PS $24^{\mathrm{T}}$ were found to be $59.6 \%$ and $60.2 \%$, respectively. Assessments of ANI scores and $\mathrm{dDDH}$ values of PS14 $4^{\mathrm{T}}, \mathrm{PS} 24^{\mathrm{T}}$ and closely related strains are listed in Table S3. The highest correlations were between $\mathrm{PS} 14^{\mathrm{T}}$ and $P$. helmanticensis, with an ANI score of $88.3 \%$ and a dDDH score of $35.7 \%$, and between PS2 $2{ }^{\mathrm{T}}$ and $P$. qingdaonensis, with an ANI score of $80.8 \%$ and a dDDH score of $24.5 \%$. These ANI and $\mathrm{dDDH}$ scores were lower than the cutoff values for species delineation ( $>95 \%$ for ANI and $>70 \%$ for $\mathrm{dDDH}$ ) [12], indicating that PS $14^{\mathrm{T}}$ and PS $24^{\mathrm{T}}$ are likely novel species of the genus Pseudomonas.

\section{Chemotaxonomic Characterization}

The major fatty acids detected in the Izu Oshima strains were found to be $\mathrm{C}_{16: 0}, \mathrm{C}_{17: 0 \text { cyclo }}$, summed feature $3\left(\mathrm{C}_{16: 1} \omega 6 \mathrm{c}\right.$ and/ or $\left.\mathrm{C}_{16: 1} \omega 7 \mathrm{c}\right)$, and summed feature $8\left(\mathrm{C}_{18: 1} \omega 7 \mathrm{c}\right.$ and/or $\left.18: 1 \omega 6 \mathrm{c}\right)$ (Table 1). This profile is similar to that of related strains. Both PS14 ${ }^{\mathrm{T}}$ and PS2 $24^{\mathrm{T}}$ possess three fatty acids generally detected in the genus Pseudomonas, namely $\mathrm{C}_{10: 0} 3-\mathrm{OH}, \mathrm{C}_{12: 0}$ and $\mathrm{C}_{12: 0} 3-\mathrm{OH}$ [11]. 
Table 1 Cellular fatty acid content of PS14 ${ }^{\mathrm{T}}, \mathrm{PS} 24^{\mathrm{T}}$ and closely related strains

\begin{tabular}{lllllllllll}
\hline & 1 & 2 & 3 & 4 & 5 & 6 & 7 & 8 & 9 & 10 \\
\hline $\mathrm{C}_{12: 0} 2 \mathrm{OH}$ & 5.3 & 2.8 & 4.9 & 6.4 & 4.7 & 6.2 & 2.9 & 2.8 & 4.0 & 9.0 \\
$\mathrm{C}_{12: 0} 3 \mathrm{OH}$ & 4.5 & 3.5 & 2.9 & 4.0 & 2.5 & 5.1 & 4.2 & 3.5 & 3.9 & 3.4 \\
$\mathrm{C}_{10: 0} 3 \mathrm{OH}$ & 3.2 & 3.3 & 2.4 & 3.6 & 3.2 & 4.2 & 2.2 & 1.5 & 4.3 & 8.4 \\
$\mathrm{C}_{12: 00}$ & 1.6 & 4.3 & 2.0 & 2.1 & 1.5 & 5.0 & 5.7 & 4.9 & 6.2 & 3.0 \\
$\mathrm{C}_{16: 00}$ & 32.8 & 29.1 & 31.9 & 30.0 & 31.9 & 20.0 & 19.3 & 25.6 & 30.0 & 27.5 \\
$\mathrm{C}_{17: 0}$ cyclo & 11.5 & 7.0 & 5.1 & 2.0 & 6.9 & 1.5 & $\mathrm{ND}$ & 1.7 & 8.6 & 8.2 \\
$\mathrm{C}_{18: 00}$ & $\mathrm{TR}$ & $\mathrm{TR}$ & $\mathrm{TR}$ & $\mathrm{TR}$ & $\mathrm{TR}$ & $\mathrm{TR}$ & 1.7 & $\mathrm{ND}$ & $\mathrm{TR}$ & $\mathrm{TR}$ \\
Summed feature 3 & 27.2 & 32.6 & 32.9 & 42.4 & 35.6 & 41.9 & 35.4 & 37.2 & 33.4 & 25.8 \\
Summed feature $8^{\mathrm{b}}$ & 10.7 & 15.3 & 15.6 & 8.5 & 12.4 & 13.4 & 27.8 & 21.2 & 7.4 & 11.4 \\
\hline
\end{tabular}

Strains were cultured on TSA at $28^{\circ} \mathrm{C}$ for $24 \mathrm{~h}$

1, PS14 ${ }^{\mathrm{T}} ; 2$, PS24 $4^{\mathrm{T}} ; 3$, P. helmanticensis $\mathrm{OHA} 11^{\mathrm{T}} ; 4$, P. baetica $\mathrm{a} 390^{\mathrm{T}} ; 5$, P. granadensis DSM $28040^{\mathrm{T}} ; 6$, P. koreensis $9-14^{\mathrm{T}} ; 7$, P. rhizosphaerae $\mathrm{IH}^{\mathrm{T}} ; 8$, P. lutea $\mathrm{OK}^{\mathrm{T}} ; 9$, P. bohemica $\mathrm{IA}^{\mathrm{T}}$; $10, P$. qingdaonensis $\mathrm{JJ}_{3}{ }^{\mathrm{T}}$. Data from taxa 3 to 5 are from reference [13], and taxa 7 and 8 are from reference [14] using the same conditions. Fatty acids ( $>1 \%$ of total fatty acids) are shown

$N D$ not detected, TR trace (Fatty acid amount $<1 \%$ )

${ }^{\mathrm{a}} \mathrm{C}_{16: 1} \omega 6 \mathrm{c}$ and/or $\mathrm{C}_{16: 1} \omega 7 \mathrm{c}$ and/or $\mathrm{C}_{15.0}$ ISO 2-OH

${ }^{\mathrm{b}} \mathrm{C}_{18: 1} \omega 7 \mathrm{c}$ and/or ${ }_{18: 1} \omega 6 \mathrm{c}$

\section{Growth Conditions, Physiology, Morphology, and Biochemical Characteristics}

The phenotypic features of PS $14^{\mathrm{T}}$ and PS $24^{\mathrm{T}}$ are presented in Table 2. The phenotypic features of PS14 ${ }^{\mathrm{T}}$ were similar to those of $P$. koreensis, although they differed in utilization of gelatin hydrolysis, D-fucose, D-arabitol, L-histidine, glucuronamide, and $\alpha$-keto-glutaric acid. PS24 ${ }^{\mathrm{T}}$ was found to be more restricted than PS14 ${ }^{\mathrm{T}}$, with D-glucose being the only sugar source found to be utilized by PS2 $24^{\mathrm{T}}$.

\section{Description of Pseudomonas atagosis sp. nov.}

This strain, which has been named for Atago Mountain, the source of the original sample, was found to be Gramnegative, motile, rod-shaped, oxidase-positive, and catalasepositive. Cells were observed to be $1.0-1.7 \mu \mathrm{m}$ long and $0.4-0.6 \mu \mathrm{m}$ wide. Colonies grown on TSA agar for $24 \mathrm{~h}$ at $28{ }^{\circ} \mathrm{C}$ were moist and creamy-white in color due to extracellular substances. Concentrated cell pellet was beigecolored. Growth was observed at temperatures of $5-32{ }^{\circ} \mathrm{C}$, with optimum growth at $24-28^{\circ} \mathrm{C}$. The strain could grow in the presence of $0-4 \%(\mathrm{w} / \mathrm{v}) \mathrm{NaCl}$ and at $\mathrm{pH}$ between 5 and 8 and produced a fluorescent pigment when grown on King $\mathrm{B}$ agar. Major fatty acids were $\mathrm{C}_{16: 0}, \mathrm{C}_{17: 0}$ cyclo, summed feature $3\left(\mathrm{C}_{16: 1} \omega 6 \mathrm{c}\right.$ and/or $\left.\mathrm{C}_{16: 1} \omega 7 \mathrm{c}\right)$, and summed feature $8\left(\mathrm{C}_{18: 1} \omega 7 \mathrm{c}\right.$ and/or $\left.{ }_{18: 1} \omega 6 \mathrm{c}\right)$. On API $20 \mathrm{NE}$ tests, this strain was positive for $\mathrm{L}$-arginine, gelatin, D-glucose, $\mathrm{L}$-arabinose, D-mannose, D-mannitol, $\mathrm{N}$-acetyl-glucosamine, potassium gluconate, capric acid, malic acid, and trisodium citrate. Biolog GEN III Microplate assays showed that these bacteria can utilize $\alpha$ - D-glucose, D-mannose, D-fructose, D-galactose, D-fucose, inosine, D-mannitol, glycerol, L-alanine,
L-arginine, L-aspartic acid, L-glutamic acid, L-pyroglutamic acid, L-serine, D-gluconic acid, glucuronamide, mucic acid, quinic acid, D-saccharic acid, L-lactic acid, citric acid, $\alpha$-keto-glutaric acid, L-malic acid, $\gamma$-amino-butryric acid, $\beta$-hydroxy-D L-butyric acid, propionic acid, and acetic acid and was able to grow in the presence of $1 \%$ sodium lactate, fusidic acid, D-serine, troleandomycin, rifamycin SV, lincomycin, guanidine $\mathrm{HCl}$, niaproof 4 , vancomycin, tetrazolium violet, tetrazolium blue, nalidixic acid, lithium chloride, potassium tellurite, and aztreonam. The $\mathrm{G}+\mathrm{C}$ content of the type strain is $59.58 \%$. The type strain, $\mathrm{PS}_{14}{ }^{\mathrm{T}}$ (=CECT $9940^{\mathrm{T}}$, = LMG $31496^{\mathrm{T}}$ ), was isolated from soil collected at Mt. Atago, which is located in the northwest part of Izu Oshima, Tokyo, Japan.

\section{Description of Pseudomonas akappagea sp. nov.}

This strain, which has been named for the source of the original sample, the coastal area of Izu Oshima island, called "Akappage" by the local inhabitants, was found to be Gramnegative, motile, rod-shaped, oxidase-positive, and catalasepositive. The cells were $1.25-2.0 \mu \mathrm{m}$ long and $0.5-0.7 \mu \mathrm{m}$ wide. Colonies grown on TSA agar for $24 \mathrm{~h}$ at $28{ }^{\circ} \mathrm{C}$ were beige in color. Growth was observed at $5-36{ }^{\circ} \mathrm{C}$, with optimum growth at $24-28{ }^{\circ} \mathrm{C}$. These bacteria could grow in the presence of $0-3 \%(\mathrm{w} / \mathrm{v}) \mathrm{NaCl}$ and at $\mathrm{pH}$ between 5 and 8 but did not produce a fluorescent pigment when grown on King $\mathrm{B}$ agar. Major fatty acids were $\mathrm{C}_{16: 00}, \mathrm{C}_{17: 0}$ cyclo, summed feature $3\left(\mathrm{C}_{16: 1} \omega 6 \mathrm{c}\right.$ and/or $\left.\mathrm{C}_{16: 1} \omega 7 \mathrm{c}\right)$, and summed feature $8\left(\mathrm{C}_{18: 1} \omega 7 \mathrm{c}\right.$ and/or $\left.{ }_{18: 1} \omega 6 \mathrm{c}\right)$. On API 20NE tests, this strain was positive for potassium nitrate, D-glucose, potassium gluconate, capric acid, adipic acid, malic acid, trisodium citrate, and phenylacetic acid. Biolog GEN III Microplate 
Table 2 Phenotypic characteristics that differentiate the strains PS14 ${ }^{\mathrm{T}}$ and PS $24^{\mathrm{T}}$ from the closely related type strains

\begin{tabular}{|c|c|c|c|c|c|c|c|c|c|c|}
\hline & 1 & 2 & 3 & 4 & 5 & 6 & 8 & 9 & 7 & 10 \\
\hline GC content $(\%)$ & 59.6 & 60.2 & 59.2 & 58.8 & 60.2 & 60.5 & 62.0 & 60.2 & 59.5 & 64.2 \\
\hline Fluorescence & + & - & + & + & - & + & - & - & - & + \\
\hline \multicolumn{11}{|c|}{ Activity of enzymes (API 20 NE test) } \\
\hline Potassium nitrate & - & + & - & - & - & - & - & - & - & - \\
\hline L-arginine & + & - & - & + & - & + & - & - & - & + \\
\hline Gelatin (bovine origin) & + & - & - & + & + & - & - & - & - & - \\
\hline \multicolumn{11}{|l|}{ Growth on (API 20 NE test) } \\
\hline D-mannose & $\mathrm{w}$ & - & + & + & + & + & + & + & - & - \\
\hline D-mannitol & + & - & + & + & + & + & + & + & + & - \\
\hline$N$-acetyl-glucosamine & + & - & + & + & + & + & - & - & - & - \\
\hline Phenylacetic acid & - & + & - & - & - & - & - & - & - & + \\
\hline \multicolumn{11}{|l|}{ Carbon sources (Biolog GN3) } \\
\hline D-galactose & + & - & + & + & $\mathrm{w}$ & + & + & $\mathrm{w}$ & + & - \\
\hline D-fucose & $\mathrm{w}$ & - & + & + & $\mathrm{w}$ & - & - & - & $\mathrm{w}$ & $\mathrm{w}$ \\
\hline Inosine & $\mathrm{w}$ & - & $\mathrm{w}$ & + & - & - & - & - & $\mathrm{w}$ & $\mathrm{w}$ \\
\hline D-arabitol & - & - & + & + & - & - & - & - & + & - \\
\hline D-fructose-6-PO4 & - & - & $\mathrm{w}$ & + & $\mathrm{w}$ & - & - & - & $\mathrm{w}$ & $\mathrm{w}$ \\
\hline D-aspartic acid & - & - & - & - & - & - & - & - & - & - \\
\hline D-serine & - & + & - & + & $\mathrm{w}$ & - & - & - & - & + \\
\hline Glycyl-L-proline & - & - & - & - & - & - & - & - & - & - \\
\hline Pectin & - & - & - & + & - & - & - & - & - & - \\
\hline D-galacturonic acid & - & - & - & - & $\mathrm{w}$ & - & - & + & + & - \\
\hline L-galactonic acid lactone & - & - & - & - & - & - & - & + & + & - \\
\hline D-glucuronic acid & - & - & + & - & $\mathrm{w}$ & - & - & + & + & - \\
\hline Glucuronamide & + & - & + & - & $\mathrm{w}$ & - & - & $\mathrm{w}$ & + & $\mathrm{w}$ \\
\hline Mucic acid & + & + & + & - & $\mathrm{w}$ & + & - & $\mathrm{w}$ & + & - \\
\hline Quinic acid & + & + & + & + & + & + & + & - & - & + \\
\hline D-saccharic acid & + & - & + & + & $\mathrm{w}$ & $\mathrm{w}$ & - & - & + & - \\
\hline p-hydroxy-phenylacetic acid & - & - & - & - & - & - & - & - & - & + \\
\hline D-malic acid & - & - & $\mathrm{w}$ & - & - & - & - & - & - & + \\
\hline Bromo-succinic acid & - & + & $\mathrm{w}$ & + & - & - & - & - & $\mathrm{w}$ & - \\
\hline Tween 40 & - & - & $\mathrm{w}$ & + & $\mathrm{w}$ & - & - & - & - & - \\
\hline$\alpha$-keto-butyric acid & - & - & - & - & - & - & - & - & - & - \\
\hline Acetoacetic acid & - & - & - & - & - & - & - & - & + & - \\
\hline
\end{tabular}

1, PS14 ${ }^{\mathrm{T}} ; 2, \mathrm{PS}_{2}^{\mathrm{T}} ; 3$, P. helmanticensis $\mathrm{OHA}_{1}^{\mathrm{T}} ; 4$, P. baetica $\mathrm{a} 390^{\mathrm{T}} ; 5$, P. granadensis DSM $28040^{\mathrm{T}} ; 6$, P. koreensis $9-14^{\mathrm{T}} ; 7$, P. rhizosphaerae $\mathrm{IH}^{\mathrm{T}} ; 8$, P. lutea $\mathrm{OK} 2^{\mathrm{T}} ; 9$, P. bohemica $\mathrm{IA}^{\mathrm{T}} ; 10$, P. qingdaonensis $\mathrm{JJ}^{\mathrm{T}}$. All data were obtained in this study, except taxon 4, which were from reference [15] and for fluorescent data of taxon 5, which were from reference [13]

+ positive, - negative, $w$ weakly positive (GN3, extremely faint color, or with small purple flecks or clumps) assays showed that these bacteria can utilize $\alpha$-D-glucose, glycerol, D-serine, L-alanine, L-arginine, L-aspartic acid, L-glutamic acid, L-histidine, L-pyroglutamic acid, L-serine, D-gluconic acid, mucic acid, quinic acid, methyl pyruvate, L-lactic acid, citric acid, $\alpha$-keto-glutaric acid, L-malic acid, bromo-succinic acid, $\gamma$-amino-butryric acid, $\beta$-hydroxy-D L-butyric acid, propionic acid, acetic acid, and formic acid and was able to grow in the presence of $1 \%$ sodium lactate, D-serine, troleandomycin, rifamycin SV, lincomycin, guanidine $\mathrm{HCl}$, niaproof 4 , vancomycin, tetrazolium violet, tetrazolium blue, potassium tellurite, and aztreonam. The $\mathrm{G}+\mathrm{C}$ content of the type strain is $60.2 \%$. The type strain, PS24 ${ }^{\mathrm{T}}\left(=\right.$ CECT $9941^{\mathrm{T}}$, = LMG $\left.31497^{\mathrm{T}}\right)$, was isolated from located on the west coast of Izu Oshima, Tokyo Japan.

Acknowledgements This study was supported by Grant-in-Aid for Challenging Exploratory Research (KAKENHI Grant No. JP26650135 issued by Japan Society for the Promotion of Science), and the MEXT (Ministry of Education, Culture, Sports and Technology)-supported Program for the Strategic Research Foundation at Private Universities (S1201013). The funders had no role in study design, data collection 
and interpretation, or the decision to submit the work for publication. The genome sequence data of $P$. helmanticensis $\mathrm{OHA} 11^{\mathrm{T}}$ was produced by the US Department of Energy Joint Genome Institute (https://www. jgi.doe.gov/) in collaboration with the user community. We thank Dr. Tadao Kunihiro of Techno Suruga Laboratory Co., Ltd for providing technical assistance and Ms. Kana Nishitani of Global Nature Club for acting as a professional field guide and sharing her geographical knowledge of Izu Oshima.

\section{Compliance with Ethical Standards}

Conflict of interest The authors declare that they have no conflicts of interest.

Open Access This article is licensed under a Creative Commons Attribution 4.0 International License, which permits use, sharing, adaptation, distribution and reproduction in any medium or format, as long as you give appropriate credit to the original author(s) and the source, provide a link to the Creative Commons licence, and indicate if changes were made. The images or other third party material in this article are included in the article's Creative Commons licence, unless indicated otherwise in a credit line to the material. If material is not included in the article's Creative Commons licence and your intended use is not permitted by statutory regulation or exceeds the permitted use, you will need to obtain permission directly from the copyright holder. To view a copy of this licence, visit http://creativecommons.org/licenses/by/4.0/.

\section{References}

1. Peix A, Ramírez-Bahena MH, Velázquez E (2018) The current status on the taxonomy of Pseudomonas revisited: an update. Infect Genet Evol 57:106-116. https://doi.org/10.1016/j.meegi d.2017.10.026

2. Tohya M, Watanabe S, Teramoto K, Uechi K, Tada T, KuwaharaArai K, Kinjo T, Maeda S, Nakasone I, Zaw NN, Mya S, Zan KN, Tin HH, Fujita J, Kirikae T (2019) Pseudomonas asiatica sp. nov., isolated from hospitalized patients in Japan and Myanmar. Int $\mathrm{J}$ Syst Evol Microbiol 69(5):1361-1368. https://doi.org/10.1099/ ijsem. 0.003316

3. Mulet M, Sanchez D, Lalucat J, Lee K, Garcia-Valdes E (2015) Pseudomonas alkylphenolica sp. nov., a bacterial species able to form special aerial structures when grown on p-cresol. Int J Syst Evol Microbiol 65(11):4013-4018. https://doi.org/10.1099/ijsem .0 .000529

4. King EO, Ward MK, Raney DE (1954) Two simple media for the demonstration of pyocyanin and fluorescin. J Lab Clin Med 44(2):301-307

5. Sasser M (1990) Identification of bacteria by gas chromatography of cellular fatty acids, MIDI Technical Note 101. MIDI Inc, Newark, DE
6. Tohya M, Watanabe S, Teramoto K, Shimojima M, Tada T, Kuwahara-Arai K, War MW, Mya S, Tin HH, Kirikae T (2019) Pseudomonas juntendi sp. nov., isolated from patients in Japan and Myanmar. Int J Syst Evol Microbiol. https://doi.org/10.1099/ ijsem. 0.003623

7. Kumar S, Stecher G, Tamura K (2016) MEGA7: Molecular evolutionary genetics analysis version 7.0 for bigger datasets. Mol Biol Evol 33(7):1870-1874. https://doi.org/10.1093/molbev/msw054

8. Tamura K (1992) Estimation of the number of nucleotide substitutions when there are strong transition-transversion and $\mathrm{G}+\mathrm{C}$-content biases. Mol Biol Evol 9(4):678-687. https://doi.org/10.1093/ oxfordjournals.molbev.a040752

9. Felsenstein J (1981) Evolutionary trees from DNA sequences: a maximum likelihood approach. J Mol Evol 17(6):368-376

10. Lee I, Ouk Kim Y, Park SC, Chun J (2016) OrthoANI: An improved algorithm and software for calculating average nucleotide identity. Int J Syst Evol Microbiol 66(2):1100-1103. https:// doi.org/10.1099/ijsem.0.000760

11. Meier-Kolthoff JP, Auch AF, Klenk HP, Göker M (2013) Genome sequence-based species delimitation with confidence intervals and improved distance functions. BMC Bioinform 14:60. https://doi. org/10.1186/1471-2105-14-60

12. Goris J, Konstantinidis KT, Klappenbach JA, Coenye T, Vandamme P, Tiedje JM (2007) DNA-DNA hybridization values and their relationship to whole-genome sequence similarities. Int J Syst Evol Microbiol 57(Pt 1):81-91. https://doi.org/10.1099/ ijs.0.64483-0

13. Pascual J, Garcia-Lopez M, Bills GF, Genilloud O (2015) Pseudomonas granadensis sp. nov., a new bacterial species isolated from the Tejeda, Almijara and Alhama Natural Park, Granada. Spain. Int J Syst Evol Microbiol 65(Pt 2):625-632. https://doi. org/10.1099/ijs.0.069260-0

14. Menendez E, Ramirez-Bahena MH, Fabryova A, Igual JM, Benada O, Mateos PF, Peix A, Kolarik M, Garcia-Fraile P (2015) Pseudomonas coleopterorum sp. nov., a cellulase-producing bacterium isolated from the bark beetle Hylesinus fraxini. Int J Syst Evol Microbiol 65(9):2852-2858. https://doi.org/10.1099/ ijs.0.000344

15. Furmanczyk EM, Kaminski MA, Lipinski L, Dziembowski A, Sobczak A (2018) Pseudomonas laurylsulfatovorans sp. nov., sodium dodecyl sulfate degrading bacteria, isolated from the peaty soil of a wastewater treatment plant. Syst Appl Microbiol 41(4):348-354. https://doi.org/10.1016/j.syapm.2018.03.009

Publisher's Note Springer Nature remains neutral with regard to jurisdictional claims in published maps and institutional affiliations. 